\title{
MEASUREMENT OF RADON CONCENTRATION IN IRAQI AND IMPORTED CEMENT
}

\author{
R. M. RAMADHAN \\ Physics Department - Science College - Basrah University.
}

\section{ABSTRACT:}

The determination of the radon concentration that emitted from one of the important building materials which enter directly in our life, the cement, is carried out by using Solid State Nuclear Track Detector (SSNTDs).The samples of cement from different origins \{Iraq (UM QASER, KOFA, ERBIL, SULAYMANIYAH) cement ,Iranian (SHAHREKORD, BOSHER, SEPAHAN,FARS) cement, Indian (SANGHI, HATHI), cement, Pakistani (EAGLE , CAMEL, FALCON ) cement, Kuwaiti (Kuwait ) cement, K.S.A.( Al-QASEM ) cement and U.A.E. (STAR, SHARJAH ) cement) are collected. The results show that the average of maximum value of radon concentration was $37.188 \mathrm{~Bq} / \mathrm{m}^{3}$ which emitted from Pakistani cement, and the average minimum value was $28 \mathrm{~Bq} / \mathrm{m}^{3}$ which emitted from Iraqi cement. The range of the effective dose for workers in this field was from $0.1139 \mathrm{mSv} / \mathrm{y}$ to $0.2038 \mathrm{mSv} / \mathrm{y}$ and to the visitors of the locations of the production and stores of cement was from $0.0142 \mathrm{mSv} / \mathrm{y}$ to $0.0254 \mathrm{mSv} / \mathrm{y}$.

\section{INTRODUCTION:}

Radon is a natural occurring radioactive gas which is a decay product of radium. It lies in the radioactive decay chain that begins with U-238 through a series to produce Ra-226 and subsequently $\mathrm{Rn}-222$ gas and ending in $\mathrm{Pb}$ 206[1].Uranium found in soil, rock, granite, stone, water and building material $[2,3]$, so one can say that radon may be found every where. The decay products of radon (Po-218, Po-214) are also alpha active and became airborne and attach themselves to the dust particles aerosols and water droplets in the atmosphere [3].

The exposure to high level of radon gas through breathing of air increases the risk of lung cancer, where alpha particles can cause damage to tissues as well as the DNA in the cells nuclei [4, 5]. Since cement is a commonly used building material, the natural level of radioactivity in it give rise to external exposure caused by $\gamma$-ray originating from the members of the uranium ( U238 ) and thorium ( Th-232) and internal exposure mainly affecting the respiratory tract caused by the short-lived daughter products of 
radon [6,7].However, the internal exposure to radon daughter products is more damage than that to radon gas itself because of their attachment on the lung tissue, while radon may exhaled.

In the present work, the concentration of radon gas emitted from cement of different origins is measured by using the Solid State Nuclear Track Detectors (SSNTDs) technique.

\section{EXPERMANTAL:}

For measurement of radon concentration in samples of cement, Solid State Nuclear Detectors (SSNTDs) type LR-115 (cellulose nitrate), manufactured by Kodak-Pathe, France, are used. The plastic track detector is cut into pieces of size $1 \mathrm{~cm} \times 1 \mathrm{~cm}$ which are fixed inside plastic tubes of
$5 \mathrm{~cm}$ in diameter and $10 \mathrm{~cm}$ in height. Each plastic tube contains a sample of cement of ( 87 $\mathrm{gm}$ ) in the bottom as shown in Fig.(1).The samples of cement are collected from different types of Iraqi cement (different origins, trademark and factory ) and group of imported cement to Iraq ( Iranian, Indian, Pakistani, U.A.E., K. S. A. and Kuwaiti cement ) .

After exposure time of 120 days, the LR- 115 detectors are collected and etched in $2.5 \mathrm{~N}$ of sodium hydroxide $\mathrm{NaOH}$ solution at a temperature $60 \mathrm{C}^{\circ}$ with etching time $90 \mathrm{~min}$. At the end of etching process, the detectors were washed by distilled water and then dried. The count of alpha particles tracks achieved by using an optical microscope (type olompys) with magnification of $(400 \mathrm{X})$.

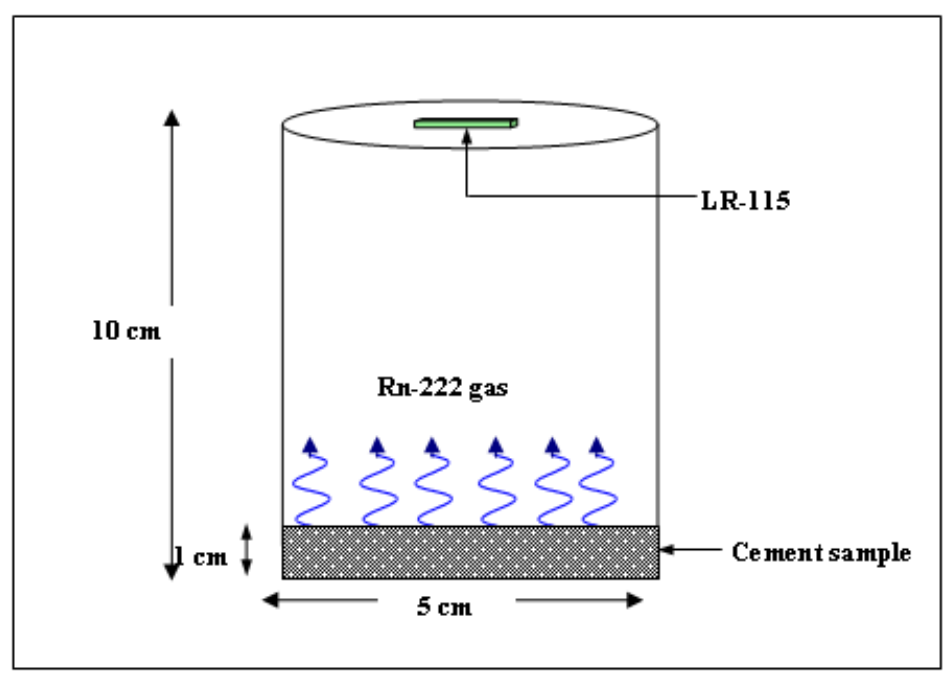

Fig. (1) The plastic tube used in this work.

\section{RESULTS AND DISCUSSION:}

The result of radon concentrations in cement samples were calculated by using the following relation [8].
$\mathbf{C R n}_{\mathrm{Rn}}\left(\mathrm{Bq} / \mathrm{m}^{3}\right)=\mathbf{K} \boldsymbol{\rho c} / \mathbf{T}_{\mathrm{c}}$ where $\mathbf{C R n}_{\mathrm{Rn}}$ is the radon concentration by $\left(\mathrm{Bq} / \mathrm{m}^{3}\right)$ where $1 \mathrm{~Bq}=$ dist $/ \mathrm{sec}, \mathbf{K}$ is the calibration factor by (Bq.d.m²/ Track.cm²), $\boldsymbol{\rho}_{\mathrm{c}}$ is track density $\left(\mathrm{T} / \mathrm{cm}^{2}\right)$ where $\mathrm{T}$ is number of track, $\mathbf{T}_{\mathrm{c}}$ is the exposure time for cement sample by days $(\mathrm{d})$. 
Table (1) shows the measured values of radon concentrations for different samples of cement $\mathrm{Bq} / \mathrm{m}^{3}$ is appear in Pakistani cement of trademark $C A M E L$, and low concentration of radon gas $22.395 \mathrm{~Bq} / \mathrm{m}^{3}$ in Iraqi cement of trademark ERBIL, while the results for the remainder samples of cement are ranged from $23.373 \mathrm{~Bq} / \mathrm{m}^{3}$ to $38.104 \mathrm{~Bq} / \mathrm{m}^{3}$ as shown in Fig. (2). However, where high value of radon concentration 40.069

the radon concentrations in all cement samples are found to be within the allowed values that given by International Commission of Radiation Protection ( ICRP ) agency which is 200-600 $\mathrm{Bq} / \mathrm{m}^{3}$ for homes and $500-1500 \mathrm{~Bq} / \mathrm{m}^{3}$ for workplaces[9,10].

Table (1): The radon gas concentrations $\left(\mathrm{Bq} / \mathrm{m}^{3}\right)$ and working level month (WLM) for worker, visitor, and equivalent dose $(\mathrm{mSv} / \mathrm{y})$ for worker and visitor.

\begin{tabular}{|c|c|c|c|c|c|c|c|c|c|}
\hline SrH & Country & $\begin{array}{c}\text { Cement } \\
\text { Trademark }\end{array}$ & $\begin{array}{l}\text { Label of } \\
\text { Sample }\end{array}$ & $\begin{array}{c}\text { Track } \\
\text { Dersity } \\
\left(\mathrm{T} / \mathrm{cm}^{2}\right)\end{array}$ & $\begin{array}{c}\text { Concentration } \\
\text { of Radon } \\
\left(\mathrm{B} q / \mathrm{m}^{3}\right)\end{array}$ & $\begin{array}{c}\text { Working } \\
\text { Level } \\
\text { Month } \\
\text { (WLM ) } \\
\text { for worker }\end{array}$ & $\begin{array}{c}\text { Working } \\
\text { Level } \\
\text { Month } \\
\text { (WLM ) } \\
\text { for } \\
\text { visitor }\end{array}$ & $\begin{array}{c}\text { Effective } \\
\text { Dose } \\
\text { (mSv/y) } \\
\text { for } \\
\text { worker }\end{array}$ & $\begin{array}{c}\text { Effective } \\
\text { Dose } \\
\text { (mSv/y) } \\
\text { for } \\
\text { visitor }\end{array}$ \\
\hline 1 & $\operatorname{IRAQ}$ & $\begin{array}{c}\text { UM } Q A S E R \\
K O F A \\
\text { ERBIL } \\
\text { SULAYMANIYAH }\end{array}$ & $\begin{array}{l}\text { I1 } \\
\text { I2 } \\
\text { I3 } \\
\text { I4 }\end{array}$ & $\begin{array}{l}152 \\
167 \\
114 \\
137\end{array}$ & $\begin{array}{l}29.855 \\
32.801 \\
22.395 \\
26.909\end{array}$ & $\begin{array}{l}0.03037 \\
0.03337 \\
0.02278 \\
0.02737\end{array}$ & $\begin{array}{l}0.00379 \\
0.00417 \\
0.00284 \\
0.00342\end{array}$ & $\begin{array}{l}0.1518 \\
0.1668 \\
0.1139 \\
0.1368\end{array}$ & $\begin{array}{l}0.0189 \\
0.0208 \\
0.0142 \\
0.0171\end{array}$ \\
\hline & Average & & $I$ & 143 & 28 & 0.02850 & 0.00355 & 0.1423 & 0.0177 \\
\hline 2 & IRAN & $\begin{array}{c}\text { SHAHREKORD } \\
\text { BOSHER } \\
\text { SEPAHAN } \\
\text { FARS }\end{array}$ & $\begin{array}{l}\text { R1 } \\
\text { R2 } \\
\text { R3 } \\
\text { R4 }\end{array}$ & $\begin{array}{l}164 \\
119 \\
176 \\
180\end{array}$ & $\begin{array}{l}32.212 \\
23.373 \\
34.564 \\
35.355\end{array}$ & $\begin{array}{l}0.03277 \\
0.02378 \\
0.03516 \\
0.03597\end{array}$ & $\begin{array}{l}0.00409 \\
0.00297 \\
0.00437 \\
0.00449\end{array}$ & $\begin{array}{l}0.1638 \\
0.1189 \\
0.1758 \\
0.1798\end{array}$ & $\begin{array}{l}0.0204 \\
0.0148 \\
0.0218 \\
0.0224\end{array}$ \\
\hline 3 & NNDEI & $\begin{array}{c}\text { SANGHI } \\
\text { HATHI }\end{array}$ & $\begin{array}{l}\text { D1 } \\
\text { D2 }\end{array}$ & $\begin{array}{l}182 \\
194\end{array}$ & $\begin{array}{l}35.747 \\
38.104\end{array}$ & $\begin{array}{l}0.03637 \\
0.03877\end{array}$ & $\begin{array}{l}0.00454 \\
0.00484\end{array}$ & $\begin{array}{l}0.1818 \\
0.1938\end{array}$ & $\begin{array}{l}0.0227 \\
0.0242\end{array}$ \\
\hline & Average & & $\mathrm{D}$ & 188 & 36.926 & 0.03757 & 0.00469 & 0.1878 & 0.0234 \\
\hline 4 & PAKSTAN & $\begin{array}{l}\text { EAGLE } \\
\text { CAMEL } \\
\text { FALCON }\end{array}$ & $\begin{array}{l}\text { P1 } \\
\text { P2 } \\
\text { P3 }\end{array}$ & $\begin{array}{l}190 \\
204 \\
174\end{array}$ & $\begin{array}{l}37.319 \\
40.069 \\
34.176\end{array}$ & $\begin{array}{l}0.03797 \\
0.04076 \\
0.03477\end{array}$ & $\begin{array}{l}0.00474 \\
0.00509 \\
0.00434\end{array}$ & $\begin{array}{l}0.1898 \\
0.2038 \\
0.1738\end{array}$ & $\begin{array}{l}0.0237 \\
0.0254 \\
0.0217\end{array}$ \\
\hline & Average & & $\mathrm{P}$ & 189 & 37.188 & 0.03783 & 0.00472 & 0.1891 & 0.0236 \\
\hline 5 & KUWET & KUWAIT & $\mathrm{K} 1$ & 163 & 32.015 & 0.03257 & 0.00407 & 0.1628 & 0.0203 \\
\hline & Average & & $\mathrm{K}$ & 163 & 32.015 & 0.03257 & 0.00407 & 0.1628 & 0.0203 \\
\hline
\end{tabular}


The measurement of the exposure to radiation for the workers and visitors of the cement factories and stores is very important, and one can say that the exposure is mainly due to decay products of radon gas which may be inhaled by them. For that purpose, the radon concentration in $\mathrm{Bq} / \mathrm{m}^{3}$ was estimated by working level (WL) unit. Progeny concentration in WL unit is obtained by dividing radon concentration in $\mathrm{Bq} / \mathrm{m}^{3}$ by 3,700 and multiplying by equilibrium factor $F$ which has been taken as 0.4, as suggested by UNSEAR,2000[10].

If a person is exposed for $170 \mathrm{~h}$ ( 1 month) to $1 \mathrm{WL}$ progeny concentration, the exposure is 1 Working Level Month (WLM). According to the ICRP-65 dose conversion convention, the effective dose per unit of exposure at work is 5 $\mathrm{mSv}$ per WLM [11].So that to calculate annual Working Level Month (WLM) and calculated the effective dose affecting both the workers and visitors to the locations of production or storing the cement one can use the following equation [12] :

$\mathrm{WLM}=\mathrm{CRn}\left(\mathrm{Bq} / \mathrm{m}^{3}\right) \times \mathrm{F} \times \mathrm{t} \quad / \quad 3,700\left(\mathrm{~Bq} / \mathrm{m}^{3}\right)$ per WL $\times 170 \mathrm{~h}$ per $\mathrm{WM}$ (2),

where $\mathrm{t}$ is the time spent by a person in the location of production or storing the cement per year.

For worker who spent $8 \mathrm{~h}$ for five days in a week and for 40 week per year (1600 h /yr), while for visitors spent $1 \mathrm{~h}$ for five days in a week and for 40 week per year $(200 \mathrm{~h} / \mathrm{yr})$. The values of WLM given in columns 7 and 8 in table (1) are calculated according to equation (2). Following the dose conversion convention of ICRP-65, the effective dose given in the last two columns of table (1) are estimated for each cement sample. In our results, the maximum value of effective dose received by workers was $0.2038 \mathrm{mSv} / \mathrm{y}$ and by visitors was $0.0254 \mathrm{mSv} / \mathrm{y}$, which found in Pakistani cement of CAMEL trademark. On the other hand the minimum values were 0.1139 $\mathrm{mSv} / \mathrm{y}$ and $0.0142 \mathrm{mSv} / \mathrm{y}$ for the exposure of workers and visitors, respectively, which found in
Iraqi cement of ERBIL trademark. The International Commission of Radiation Protection ICRP-65 has recommended that remedial action against radon is justified above a continued effective dose of 3-10 mSv/y [13], while an action level within the range of $0.1423 \mathrm{mSv} / \mathrm{y}$ to 0.1880 $\mathrm{mSv} / \mathrm{y}$ to workers and range of $0.0177 \mathrm{mSv} / \mathrm{y}$ to $0.0235 \mathrm{mSv} / \mathrm{y}$ to visitors. Thus, our measurement of radon concentrations that emitted from cement are below the recommendation of ICRP. The relationship between the effective dose and radon of concentration was found linear for workers and visitors as shown in Fig.[3].

\section{CONCLUSION:}

According to the results antecedent, one can conclude that the low average of radon gas concentration was equal to $28 \mathrm{~Bq} / \mathrm{m}^{3}$ which was in Iraqi cement (ERBIL cement), and high average was $36.991 \mathrm{~Bq} / \mathrm{m}^{3}$ in Pakistani cement (CAMEL cement). Thus, all the results between the minimum and the maximum values were below the allowed by the recommendation of the International Commission of Radiation Protection (ICRP). In other word, the effective dose values are within the safety range for all samples of cement finally, the relationship between radon concentration and effective dose was found linear. 


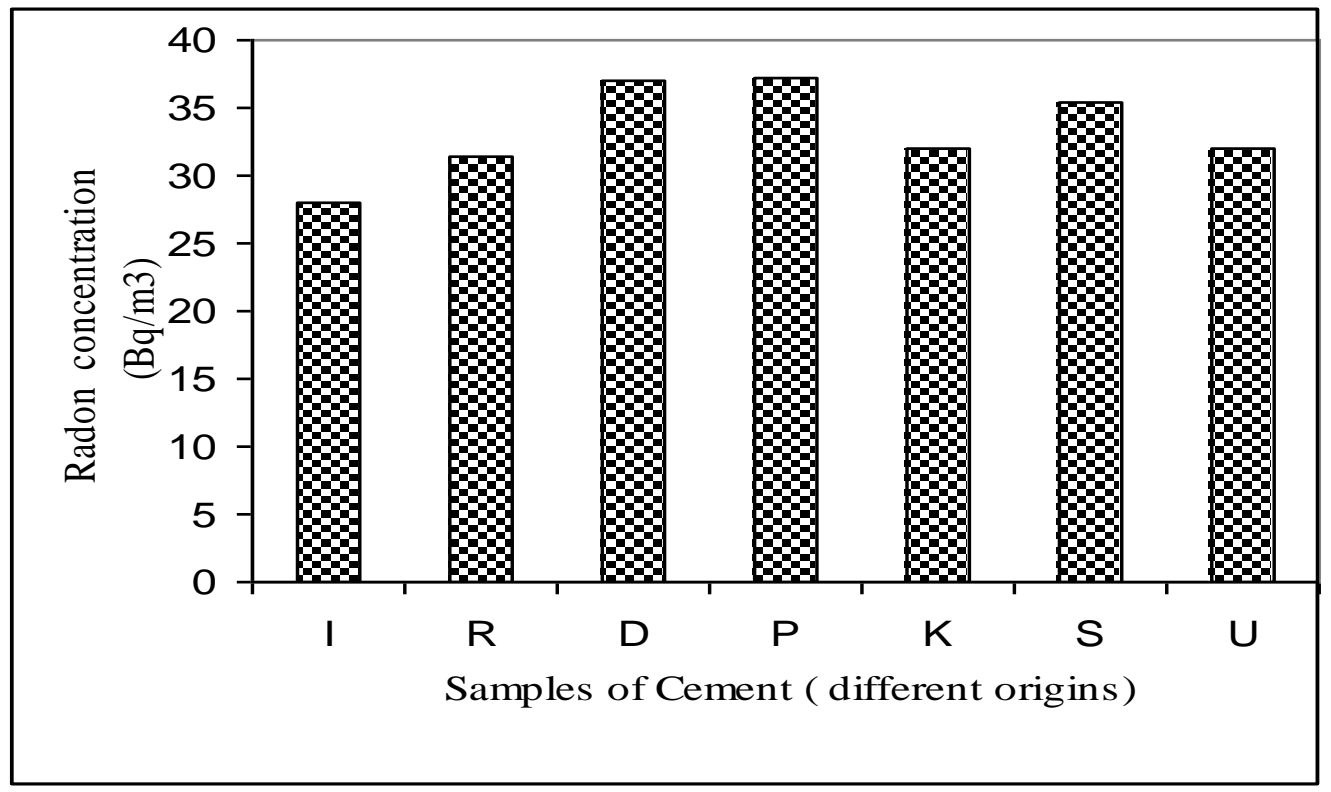

Fig. (2): Average of Radon Concentration $(\mathrm{Bq} / \mathrm{m} 3)$ to Different Samples of Cement .The labels I to $U$ are given in the 4 th column of table (1).

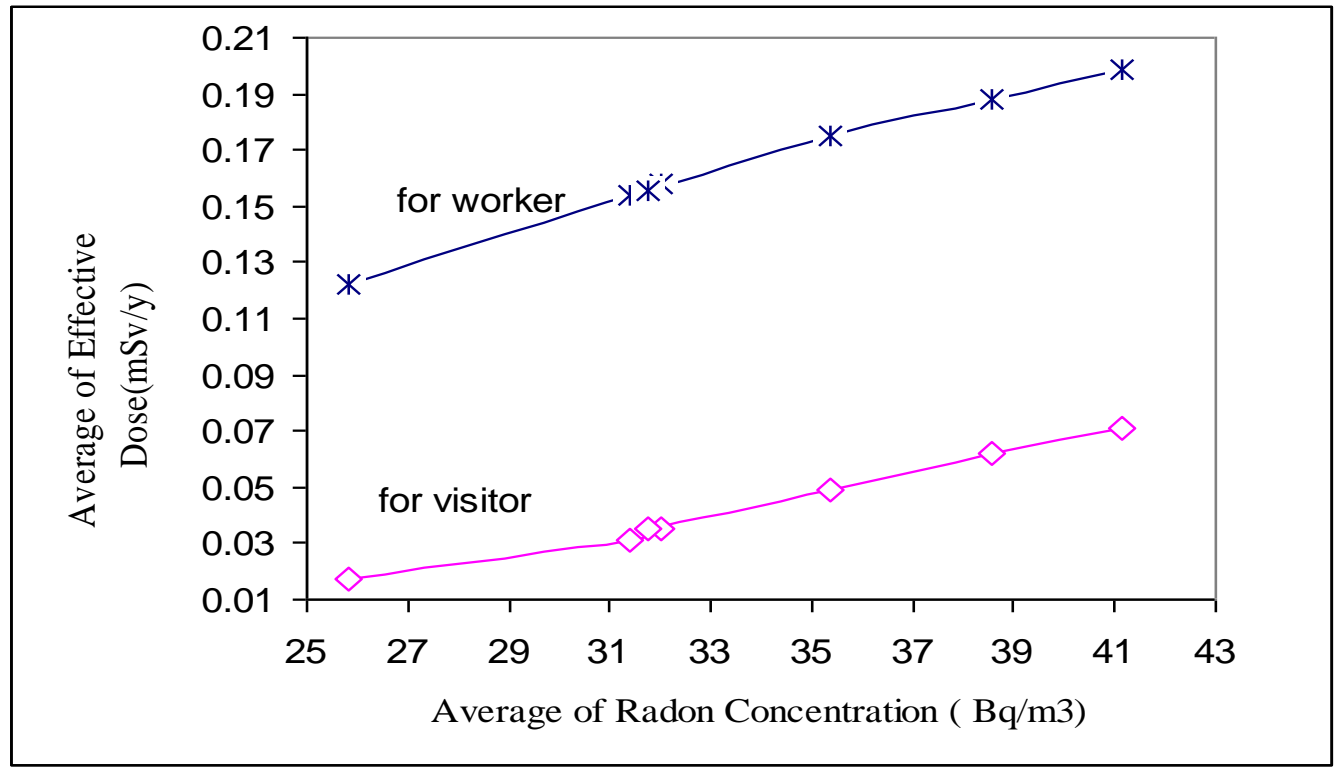

Fig. (3): Relation Between Average of Radon Concentration $\left(\mathrm{Bq} / \mathrm{m}^{3}\right)$ and Effective Dose (mSv/y). 


\section{REFERENCES:}

[1]E. Akortia, O.C.Oppon and Y. Serfor-Armah, "Indoor Radon Gas Levels in Selected Homes in the Greater Accra Region of Ghana" Research Journal of Applied Science, Engineering and Technology, Vol. 2 No.8:PP.734-742,(2010).

[2]Peter A. Ston, Robert J. Devlin, Bruce Crawfort and David G. Baize,"Uranium, Radium, and Radon in well water in south Carolina: Distribution and Problem ",(2005).

[3]Rajesh Kumar, A K Mahur, P J Jojo and Rajendra Prasad,"Study of Radon and its Progeny Levels Dwelling of Thankassery, Kerala" Indian Journal of Pure\& Applied PhysicsVol. 45, pp.877$879,(2007)$

[4]R.William Field, Ph. D. M. S., "Environmental Factors in Cancer: Radon ",( 2008).

[5]A. S. Hussein, " Radon in the environmental: Friend or Foe?",(2008).

[6]M. Nain, R. P. Chauhax, S. K. Chakarvart," Alpha radioactivity in Indiain cement samples" Iran Journal Research, Vol.3No.4: PP.171-176,(2006).
[7] Jonsson, G.," Radon Gas - where from and what to do?", Rad. Meas. Vol.28,pp 537,(1995).

[8]Raed Mohamed Abu Saleh," Measurement of Radon in Soil in the Middle of Gaza strip", M. S. theses in physics, the Islamic university of Gaza, Palestine, (2005).

[9]International Commission of Radiation Protection (ICRP)-65, Protection Against Radon-222 at home and work, Pergamon Press, Ox ford, (1994).

[10]United Nations Scientific Committee on the Effect at Atomic Radiation (UNSCEAR), Annx A: Exposure from Natural Sours. United Nation, New York,(2000).

[11] International Commission on Radiological Protection (ICRP)-65, Protection Against Radon at home and work, Pergamon Press, Ox ford, (1993).

[12]Qureshi, A. A. , Kakar , D. M. , Akram, M., Khattak, N. U. Tufail ,M. \& Mehmood, K. , et al . "Radon concentration in coal mines of Baluchistan, Pakistan "Journal of environment Radioactivity, Vol. 48, No.2, PP.203-209, (2000).

[13]United Nations Scientific Committee on the Effect at Atomic Radiation (UNSCEAR), Sources to Effects Assessment for Radon in Homes and workplaces, Report to the general Assembly, United Nation, New York,(2006).

الهدف من الدراسة هو تحديد نركيز غاز الردون -222 في واحد من أهم المواد التي تدخل الحياة مباشرتا.ألا وهو الاسمنت ,حيث جمعت

نماذج الاسمنت من مناشئ اسمنت مختلفة؛ عراقية, إيرانية, هندية, باكستانية,كوينية, سعودية و إماراتية. النتائج اظهرت ان معدل اعلى قيمة لتركيز الرادون كانت 37.188 بيكرل لكل متر مكعب في الاسمنت الباكستاني ومعدل أقل قيمه لتركيز الرادون كانت 28 بيكرل لكل متر مكعب في الاسمنت العراقي. مدى الجرع المؤثرة للعاملين في هذا المجال كان من 0.1139 ملي سيفرت لكل سنة الى 0.2038 ملي سيفرت لكل سنة و لزائري مواقع أنتاج وتخزين الاسمنت فكانت من 0.0142 ملي سيفرت لكل سنة الى 0.0254 ملي سيفرت لكل سنة. 